\title{
便潜血要精検者の精検受診率向上のための検討
}

一特に受診者の性格及び生活志向について——

$\begin{array}{lllll}\text { 小野 } & \text { 桂子, } & \text { 細江 雅彦*, } & \text { 伊藤 圭子, } & \text { 土井恵里子 } \\ \text { 窪田 } & \text { 千年, } & \text { 橋本 } \text { 広子, } & \text { 坂井 美里, 真鍋 良子 } \\ \text { 久野 } & \text { 正恵, } & \text { 高木 愛子, } & \text { 大島健次郎, } & \text { 岩田 弘敏** }\end{array}$

〈はじめに〉 大腸癌集検が普及し, 救命可能な大腸 癌が多く発見されている。しかし，一方集検を受け便 潜血検査陽性の結果が出たにも拘らず，精検を受けな い受診者は過去 5 年間平均 $40 \%$ にもなっている。集検 を受ける行動と，要精検と言われても医療機関を訪れ ないのは，どのような問題が介在しているのか興味あ ることである。第 18 回本学会にて精検の未受診理由に ついては既に報告したが, 今回は精検未受診者, 受診 者と二群に分けて両群の性格,生活志向を比較検討し, 精検未受診者になり易い性格，生活志向を調査し，今 後の事後指導，大腸集検を含む健診に対する衛生教育 の参考にしたいと考えた。

〈対象及び方法〉昭和 63 年度に当院に受診した者 は，22,197 人で，このうち便潜血陽性者は 764 人であ つた。764 人のうち医療機関受診者(以下，精検受診者 という）は 430 人 $(56.3 \%)$, 未受診者は 334 人 ( 43.7 \%)であった。このうち精検受診者 110 人，未受診者 116 人を無作為に抽出し, 平成元年 3 月より本年 2 月 までに調查した。調査方法は, 性格テストとしてYG 性格検查を簡易化し, 12 の性格を質問紙法で調查し, これを点数化し集計した。生活志向についても同様に 自分の人生において大切なものを順位づけさせる方式 で家族, 職業, 趣味, 娛楽, 経済的利益, 社会的地位, 健康等について面接法にて行った。

〈成 績〉性格テストでは, 精検受診者群, 未受診 者群で各性格を点数化すると\{( )内は前者は精検群, 後者は未受診群を表す $\}$, 抑うつ性 $(11.8,8.6)$, 気分

\footnotetext{
Comparative Studies On the Decision Making For Further Examination As to Charactor And Judgement Of Valve To Life. - Participants with Posifive Result Of Fecal Blood Testing 岐阜県立健康管理院

*和良病院内科

**岐阜大学医学部衛生学教室
}

の変化 $(29.1,20.7)$, 劣等感 $(2.7,6.0)$, 神経質 $(9.1,9.5)$, 主観的 $(7.3,13.8)$, 非協調的 $(1.8,1.7)$, 攻撃的 $(22.7,25.0)$, 活動性 $(25.6,25.0)$, のん気 な性格 $(12.7,19.8)$, 外向的思考 $(35.6,31.9)$, 支 配性 (22.7，27.6), 社交性 (57.3，58.6）で，その各 項目について両群間に有意差を示す項目はなかった。 傾向として, 未受診者群においては劣等感, 主観的, のん気な性格である割合が精検受診者を 1 とすると劣 等感 2.22 倍, 主観的 1.89 倍,のん気 1.56 倍を示した。 一方, この逆に抑うつ性性格 0.73 倍, 気分の変化の大 きい性格 0.71 倍となっていた。生活志向では精検受診 者群, 未受診者群共に第 1 位としたのは家族, 健康, 職業の順であったが，その割合は「家族」が精検受診 者群 $50.9 \%$ ，未受診者群 $51.7 \%$ ，「健康」がそれぞれ $38.2 \%, 24.1 \%$,「職業」がそれぞれ $7.3 \%$ と $16.3 \%$ であった。「家族」を第 1 位に挙げたもののうち第 2 位 の生活志向として精検受診者群では 56 例中 17 例 (30.4\%), 未受診者群では63例中 31 例 (49.2\%) が職業・ 経済を挙げている。一方, 第 2 位に健康を挙げたもの は, 精検受診者群 32 例 (57.1\%), 未受診者群 17 例 (27.0\%)であり両群に差が認められた。また, 第 1 位, 2 位を合わせてみると「家族」が 1 位で精検受診者群 と末受診者群それぞれの割合は $44.5 \%$ と $45.4 \%$ と差 はないが，「健康」では $34.9 \%$ と $21.1 \%$ と精検受診者 群に多く，「職業」「経済」では $15.6 \%$ \% $26.3 \%$ \% 受診者群に多かった。

\section{〈結 論〉}

以上の調査により次のような結論を得た。

1. 性格テストでは, 劣等感, 主観的, のん気な性格 であるものは，未受診者に多い傾向を示した。

2. 抑うつ性性格, 気分の変化の大きい性格のものは 精検受診者に多い傾向を示した。

3. 生活志向では「職業」「経済的利益」を大切にする のは，未受診者に多く，「健康」を大切と考えるのは 精検受診者に多い傾向を示した。 